\title{
Managing Risks in a Project Implementation: A Case of Awash Kombolcha Haragebeya Railway Construction Project
}

\author{
Mequanint Birhan ${ }^{1}$, Ermias Tesfaye $^{2}$ \\ ${ }^{1}$ Department of Mechanical Engineering, Mizan Tepisa University, Tepi, Ethiopia \\ ${ }^{2}$ School of Mechanical and Industrial Engineering, Addis Ababa University institute of Technology, Addis \\ Ababa, Ethiopia
}

*Principal Author: Mequanint Birhan, Department of Mechanical Engineering, Mizan Tepisa University, Tepi, Ethiopia

\begin{abstract}
Uncertainty of future events are affecting and resulting quadrupled impact on AKH project. Thus, it is imperative to thoroughly study conduct research on risk managements for the project in the Awash Kombolcha Haragebeya (AKH) railway constructing project. Compressive literature review, project site observation and interview with key informants of the project has been used for risk identification. Fuzzy logic is used to quantify the risk, AHP to sort out the sever risk which have been occurred, and system dynamics to show and modeled the causal relationship diagram. Totally 81 general \& 31project risks found from literature and by in-depth interview triangulation. However, the source of risk is 38\% client, $41 \%$ contractor and the rest has been caused by others. In contradiction to this $52 \%$ of risk is fallen by client and $39 \%$ for contractor but the rest might be on others. The diagnosed information is changed through fuzzy quantification and procured by AHP then by Venism it correlated and the output is detected. Due to that the respond is $14.8 \%$ of risk by retention, $28.4 \%$ of risk by reduction, $9.9 \%$ of risk by transfer, and $32.1 \%$ of risk by avoidance, $3.7 \%$ of risk by sharing \& $11.1 \%$ of risk by contingency allowance
\end{abstract}

Keywords: Risk management, time, cost, quality, performance, fuzzy logic, AHP, Venism

\section{INTRODUCTION}

According to (Sons, 2003), project is an endeavor in which human, material and financial resources are organized in a novel way, to undertake a unique scope of work of given specification, within constraints of cost and time, so as to achieve unitary, beneficial change, through the delivery of quantified and qualitative objectives. However as (Farnad Nasirzadeh, 2008) understanding Many construction projects have not yet secured good project goal achievement. Failure could be realized in terms of severe project delay, cost overruns, and poor quality. Railway development in Ethiopia is first and foremost focused on economic development and It is expected to significantly reduce transport costs, increase the safety and reliability of transport services, facilitate the import-export trade of the country, increase the inflow foreign direct investment, strengthen socio-cultural cohesion, technical knowledge in the country and stimulate trade and peace in the whole region (Abiselom, 2016).Railway transport is exposed for such like risks both on the rail and the new way it implies great impact of country GDP in financial and logistics. This complexity requires close attention and follow ups.

Awash Kombolcha Haragebya railway construction project is one of the progress project lead by ERC in Ethiopia. The project is used US \$1.7billion budget and the time at which Construction on the AKH railway project was initiated in October 2015 and expected to completed in October 2018 for consecutive 42 months the service is not yet active. The corporation has no risk management policies yetuntil this research data collection period was done. While the project needs more intellectual's role, the professional researchers are not participated related to risk management for this specific site. Contractors employee are 5350 direct and 2948 indirect in number, consultant also 30 engineers and client also have 70 employees. As (A. Ng, 2007) is clear that the risks involved in concession projects are significant and need to be thoroughly analyzed, researched and managed. Because the project is 
extended 2years more than the initial planned time of $\mathrm{AKH}$ railway project but now it is $65 \%$ of the overall ongoing status. This indicates that there is cost overrun \& other constraints.

The construction process is complex and characterized by many uncertainties(Jamal F.1990).Risk and uncertainty are inherent in all construction work no matter what the size of the project. (Ogunlana,2004). The study of risk begun in the renaissance when people released themselves from the constraints of the past and openly challenged the sacred beliefs'(berestein, 1998). The word "risk" comes from ancient Italian risicare which means to dare. In that sense risk is an option not fate. In the view of (Abdelazi Berra do, 2011) our freedom of choice depends from the actions we dare to take. Risk qualitatively as the potential of loss or injury resulting from exposure to hazards. A hazard being considered as source of danger that is not associated to the likelihood with which that danger will actually lead to negative consequences. Risk is often characterized by reference to potential events and consequences, or a combination of these. Or expressed in terms of a combination of the consequences of an event (including changes in circumstances) and the associated likelihood of occurrence (Australia, 2009) (Lark, 2015). Uncertainty is the state, even partial, of deficiency of information related to, understanding or knowledge of an event, its consequences or likelihood (Lark, 2015). Risk is key to innovation and high return on Investment. "All successful organizations take risks, and the most promising opportunities often involve heightened risk" (educator, 2015). Risk is intrinsic to doing business. Enterprises that manage risks effectively will thrive and produce high quality products or services where these are the organizational objectives. (Cassidy, 2006) The probability of harmful consequences, or expected losses (deaths, injuries, property, livelihoods, economic activity disrupted or environment damaged) resulting from interactions between natural or human-induced hazards and vulnerable conditions (baas, 2008).

\section{TYPES OF RISKS}

According to (A. Ng, 2007) there are two types of risks. Project risks arise from the way a project is managed or from events in its immediate microenvironment. They may include natural risks such as ground problems/weather conditions, technical problems associated with designs, plant and equipment, materials problems associated with suppliers, organizational problems associated with subcontractors, manpower problems associated with unions, contractual problems associated with Joint Venture agreements and environmental problems associated with pollution, etc. General risks are not directly associated with project strategies, yet can have a significant impact on its outcome. These normally arise from natural, political, regulatory, legal and economic events in the general macro environment surrounding the project. The five interdependent sub-processes in risk management processes are (M. Ghaharamanzadeh, 2013). Risk planning, Risk identification, according to (Fazleena B. 2013) it is the process of finding, recognizing, and recording risk. Risk analysis/assessment, Risk response, Risk monitoring. Risks in a project mutually affect and the independent risk seldom exists in reality (Zhang, 2016).As (Mosa, 2008)responding to risk in projects, they are as follows: Responses for opportunities: mitigation Risk sharing; •Insurance; and - Risk retention. Nevertheless, they provide a useful framework for thinking about how to deal with risks. (F. Cooper, 2005). Parties sharing the gain (within pre-agreed limits), normally when the cost is less than the cost plan (M. Ghaharamanzadeh, 2013). The railway engineering is a huge system work, compared with general industrial and civil construction, which has the characteristics as follow (WANG Lina, 2011):The railway station project involves multiple departments, and the related techniques are complicated and various. High Speed Train projects are exposed to risks of different natures, such as: low participation of private companies in the new railways construction, lack of skilled labor, high technology not available in the internal market, high costs with land acquisition, among others. Such risks if not managed properly can become real problems and compromise the achievement of the project objectives (Vidivelli G. 2015). Railway safety is even more questionable at road rail level crossing (LC) where the number of fatal accidents has been significant over the years. A major concern is to understand and remove the risks in railway operations in general (Abdelaziz Berrado*, 2011). Progress management is an important part of the railway station project management, and its effect directly influences the cost and even the quality. Its design and construction is far more complex than common public buildings, so as the construction management (Jian Sun1, 2014).The risk management framework mandate and commitment, continual improvement of the framework, implementing risk management and (Australia, 2009). 


\section{LITERATURE SUMMARY}

There are so many related literatures are discussed on the detail contribution to manage risks and their contribution and limitations. However only the selected 86 literatures are more relevant than other studies. Articles, thesis and other guide lines and books are used on some extent.

$>$ Some projects, managers run the risk of generating political controversy at the federal, state, or local level \& informal governance forms to more visible position

$>$ Lack of understanding in the generalness of risk and it was based on theory

$>$ Professionals in the construction industry are using techniques described in the literature concerning RM, but are not aware of it.

Timed Fault Trees (TFTs), FTA \{fault tree analysis\}, hazard and operability study (HAZOP), failure mode and effect analysis (FMEA), Functional hazard analysis,\& (ETA), Stochastic Petri Nets (SPNs), Markov models, Monte-Carlo approach, Interpretive structural modelling (ISM), MICMAC analysis, Bayesian networks, HUGIN Expert software, structural self-interaction matrix(SSIM), system dynamics (SD), fuzzy logic, Integrated fuzzy-system dynamics (SD) approach, Second moment Bayesian (SMB) model, Interpretive structural Modeling and fuzzy approach, quantitatively measure the risk interdependence, A selection framework methodology, practical framework methodology, WAA and RII analysis results, Confidence Based Scheduling Procedure (CBSP), Empirical formulas, qualitative risk analysis techniques (QRAT), quantitative decision model, A matrix-based risk propagation model, decision tree analysis (DTA), reactive risk management approach, AHP. From the literature review, as far as my knowledge is concerned, there are no published articles on road construction project risk analysis using system dynamics approach. From the above 30 types of identification, quantification, prioritizing, mitigating and response techniques by comparing and contrasting its advantage and disadvantage the three tools are selected integrative system dynamics for determination of project construction period, Imprecise and uncertain nature of different factors and relationship, fuzzy logic values of different factors affecting the concession period are determined by fuzzy numbers based on the opinions of different experts involved in the project and AHP to point out key risks and to give specific responses are effective and appropriate tools of that specific project.

\section{Methodology}

In fact, various studies are conducted in different methodologies. However, there are deficiencies due to the following factors. Mainly the type of research going to be reacted, type of project uniqueness, checklist parameters are some of them. That is why this type of research is identified it is applied cross sectional type in railway projects of Ethiopia. The research approach can be divided into two categories; Hence the deductive approach is appropriate. The research is used mixed type of research approaches. For the data that capable of quantifying in terms of cost, time and performance has been expressed and understand in such a way. For the data which have been available in numbers, percent's, and quantity it is quantitative approach of the research. The rest of the data which is much useful but could not able to express in quantitative way simply expressed in narrative known as qualitative research approach.

Both primary and secondary data sources are used. The validation of the information by making triangulation and association between different parties of the railway project. The primary data were collected through site observation record as well as in depth interview with which key informants of the project those are client engineers, labor workers, project managers, human resource department staffs, communication staffs, contract manager, and contractor project managers, Environmental Impact Analysis expert, safety expert, local employees of them, finally consultant teams. The secondary data was collected through various published and unpublished documents, such as journal articles, risk management books, principles and guidelines, for identification of risks in the global perspective. While reports, project plans, erection operational manuals, Notices and brochures are also included in the document by giving acknowledgement to the author. External sources are websites like libcat.aau.edu.et, Booksc.org, emerald insight, UNISA, Google scholar etc. are used for risk factor checklist identification. The collected data is analyzed through the appropriate software tools such as fuzzy logic set for quantification which changes the qualitative data into quantitative form, 
AHP to get the prioritized risk should have to mitigate and system dynamics to make the relationship model and rate of the risk which happened. After that attempted to display the result in tabular form and graphically. Analysis of research involves examining, categorizing, tabulating, tasting, or otherwise combining mixed evidences, to address the initial problem statement. Then after ones the risk is investigated well the rest would have considered the quadrupled constraints of the project those are quality, time, cost and performance has been calculated only if on the extent of available data sources willing too.

\section{STUDY AREA AND SAMPLING}

Awash Kombolcha Hara-Gebya railway construction project has $392 \mathrm{~km}$ line length, $40 \mathrm{~km}$ maintenance lines, and $18 \mathrm{~km}$ station lines. Total length of $428 \mathrm{~km}$ railway installation, electrification, signaling, 56 bridges, 823 culverts, 12 tunnels, 10 station buildings and 10 employees' inhabitant 2 permanent and 8 temporary camps are included under study consideration. The railway line, serving 10 stations, will directly affect 36 million Ethiopians. It will enable them to travel from Awash to Hara Gebaya in under 4 hours 45 minutes, compared to $6 \mathrm{~h} 10$ by road, in a country where private car ownership is limited to $10 \%$. Freight transport should ultimately reach 17.5 million tons annually, some twenty trains per day. The population selection will be based on the participants' experience in the AKH railway project especially in the local or indigenous scholars in railway project and other engineers. Even though any empirical formula was not employed convenient sampling in the common project sections as a stratum purposively selected key informants are covered. There are 8395 total employees are there. But from the complex nature of the railway construction project the selected key informants of work have been taken as the following; 14 employees from client, 10 employees from contractor and 1 from consultant office engineer. Total respondents of the in-depth interview are 25 in number.

\section{DiscuSSION AND ANALYSIS}

In this section the data analysis was presented in the project risk management process cycle and system. Which are risk identification, evaluation, quantification, response, mitigation and monitoring of risks. Total populations in the project are;

Table1. Total employees of the project

\begin{tabular}{|c|c|c|c|c|c|}
\hline \multicolumn{5}{|c|}{ ERC employees } & \multirow[b]{2}{*}{1} \\
\hline Administrative clerk & 1 & Bridge manager & 1 & Project manager & \\
\hline Cleaner & 11 & Contract manager & 1 & Right of way agent & 3 \\
\hline Document control & 3 & Earthwork manager & 1 & $\mathrm{~S} / \mathrm{N}$ environmentalist & 1 \\
\hline Driver & 18 & Electrical engineering & 1 & Safety expert II & 1 \\
\hline Engineer & 7 & Civil \& design engineer & 1 & Secretary & 1 \\
\hline Food supervisor & 1 & Environmentalist & 2 & Station building manager & 1 \\
\hline Laborer/gardener & 4 & Material production manager & 1 & Track works manager & 1 \\
\hline Office runner & 2 & Mechanical engineer & 1 & Tunnel manager & 1 \\
\hline Sociologist & 2 & Office engineering & 1 & Workshop \& depot manager & 1 \\
\hline \multicolumn{2}{|l|}{49} & \multicolumn{2}{|l|}{10} & 11 & \\
\hline \multicolumn{5}{|l|}{ ERC employees $=\mathbf{7 0}$} & \multirow{3}{*}{$\frac{\infty}{\mathscr{\infty}}$} \\
\hline \multicolumn{5}{|c|}{ SYSTRA MD employees $=\mathbf{3 0}$} & \\
\hline \multicolumn{4}{|c|}{ Yapi Merkezi direct employees $=\mathbf{5 3 5 0}$} & Indirect employees $=\mathbf{2 9 4 8}$ & \\
\hline
\end{tabular}

As already mentioned, data in the methodology, the source of it would in depth interview conducted to 25 respondents for the selected key informant respondents. So the following data presented in tabular form is identified their working class of respondents.

1) Catastrophe -frequently occurred risk (0.9-1)

2) Very high-less than catastrophe but it is frequent (0.7-0.89)

3) Moderate-(0.5-0.69)

4) Small-(0.3-0.49)

5) Insignificant-(0.01-0.29) 
The contractor and consultant teams are both from foreign especially Europeans and Asians. The payable loan is from European lenders. That means they are debited but our country Ethiopia carrying credited with interest. The depreciation of railway project road is $6.3 \% / y e a r$. Which indicates that the accounting value of the national property is become zero after 15-16years (Abush, 2018).

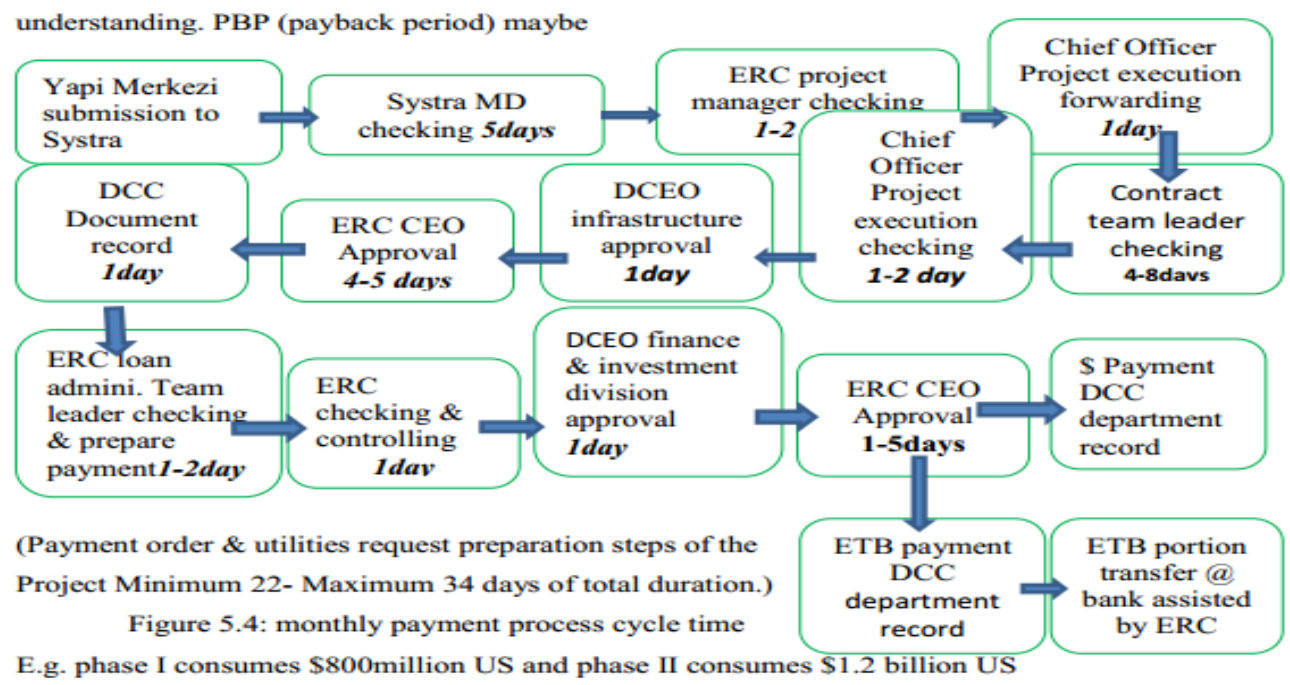

Here implies that if the project extended whenever the payback period or the initial investment cost earned(salvage) will be too.

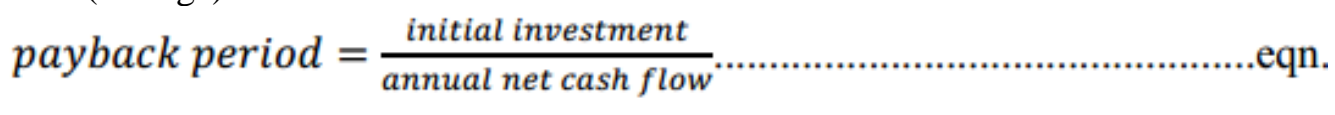

Hence will contribute to the country income statement gap \$13.5USD billion and lenders liability \$24.7USDbillion as Dr. Abush's on managerial accounting (Abush, 2018).Due to that other interrelated problems are followed nationally. The design and design review processes is too ambiguous, Design difference and uncontrollable change or improvement, Basic and detail design deviation. $=\$ 1,700,000,000$ USD

\section{$(10,000,000$ ton/year*\$0.051USD/ton $/ \mathrm{km} * 392 \mathrm{~km})$}

$=8.503401360544218$ estimated to 8years and6month.

The above has leaded another problem. Lack of quality work push to rework and maintenance that rework also needs more time stay. Contractors in Ethiopia which sentimental long live requires integration and acculturation as of yesterday's Ethiopian history witnessed.

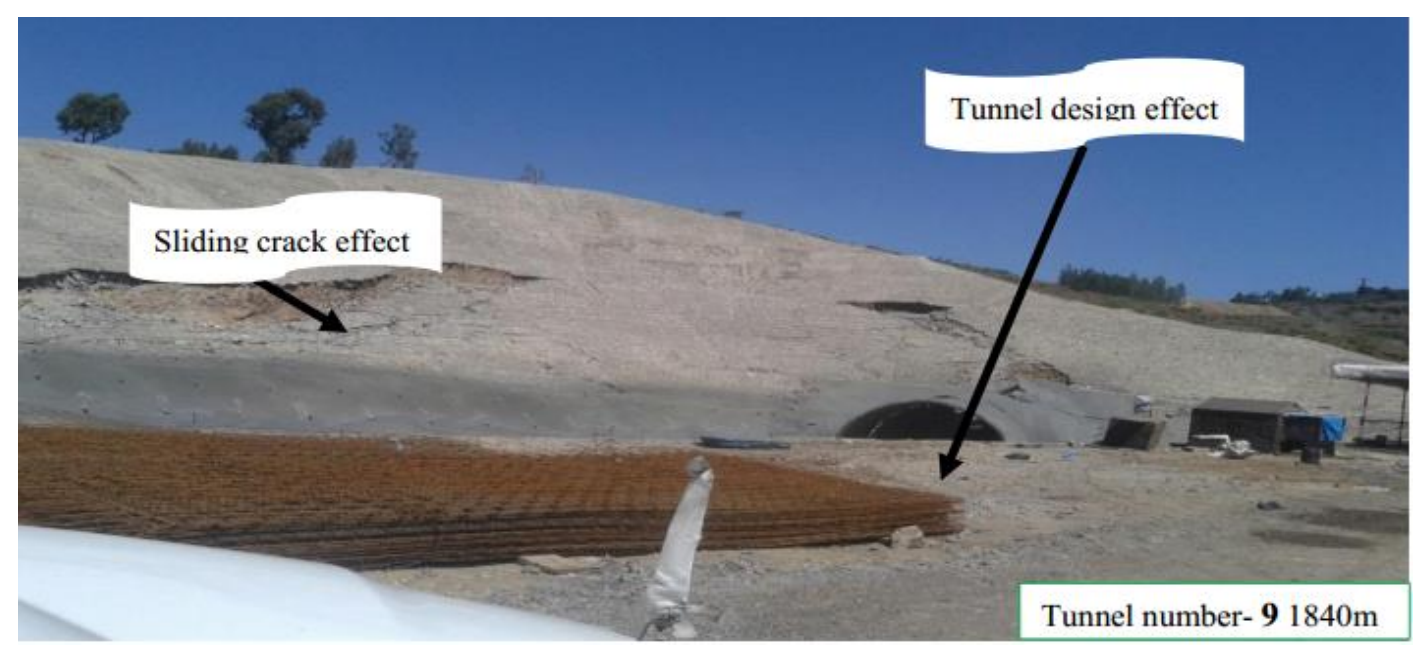

Figure1. GT-I8552 Mequanint hand phone camera March 10/2018 tunnel number of 9

Total Work to Do for project design $=$ Original Work to do + Rework to do $=4$ years $/$ project + 2.6 years $/$ project $=6.6$ years $/$ project 


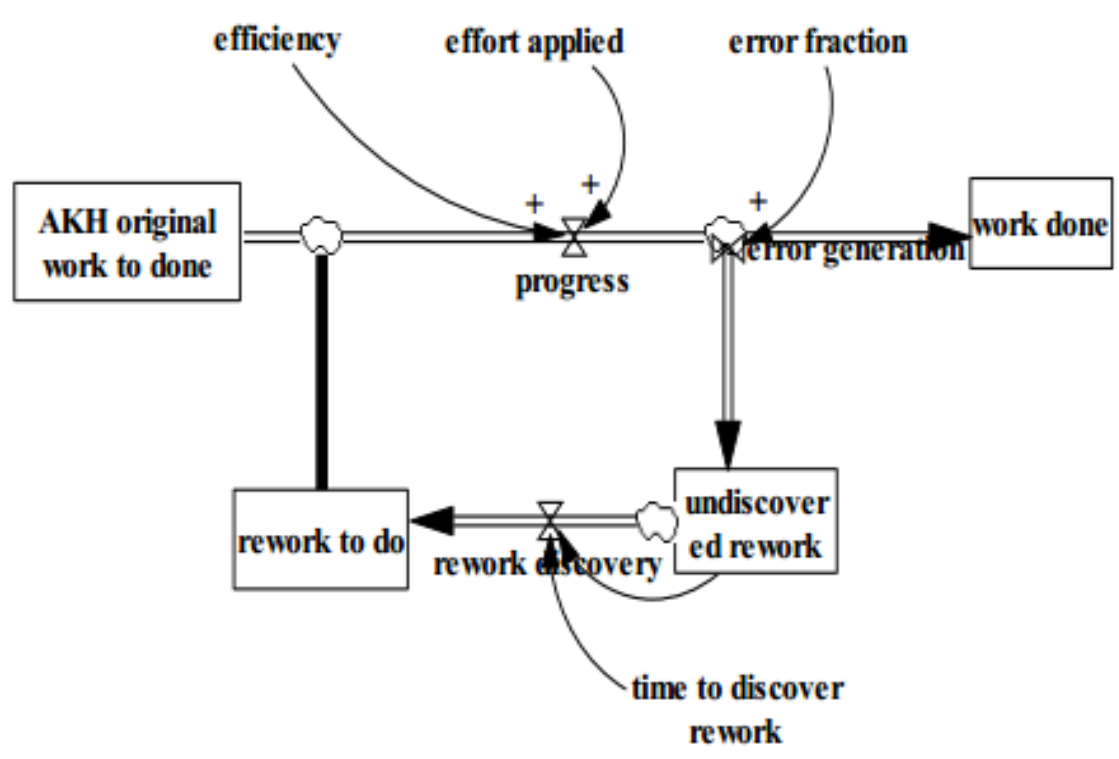

As shown in the Ta,laku tikurAmericans was started early to study the Nile river basin long period of time without sufficient reason. It had been familiar with the society and they took around 1600 number of heritages from Ethiopia. Similarly, Europeans (especially German, France, Britain \& Italy) colonial interest at the beginning of WWII to incorporate Ethiopia would affect the railway port establishment. Another important point here is also 1969EC Ethio-Somali war was related with the desire of being owner of railway between Djibouti and Ethiopia (Nigussie, 2018). So that nationally unforgettable railway operation threat will be there beyond the positive side advantage of WTO and globalization. But when the contractor is local those threats will be eliminated.

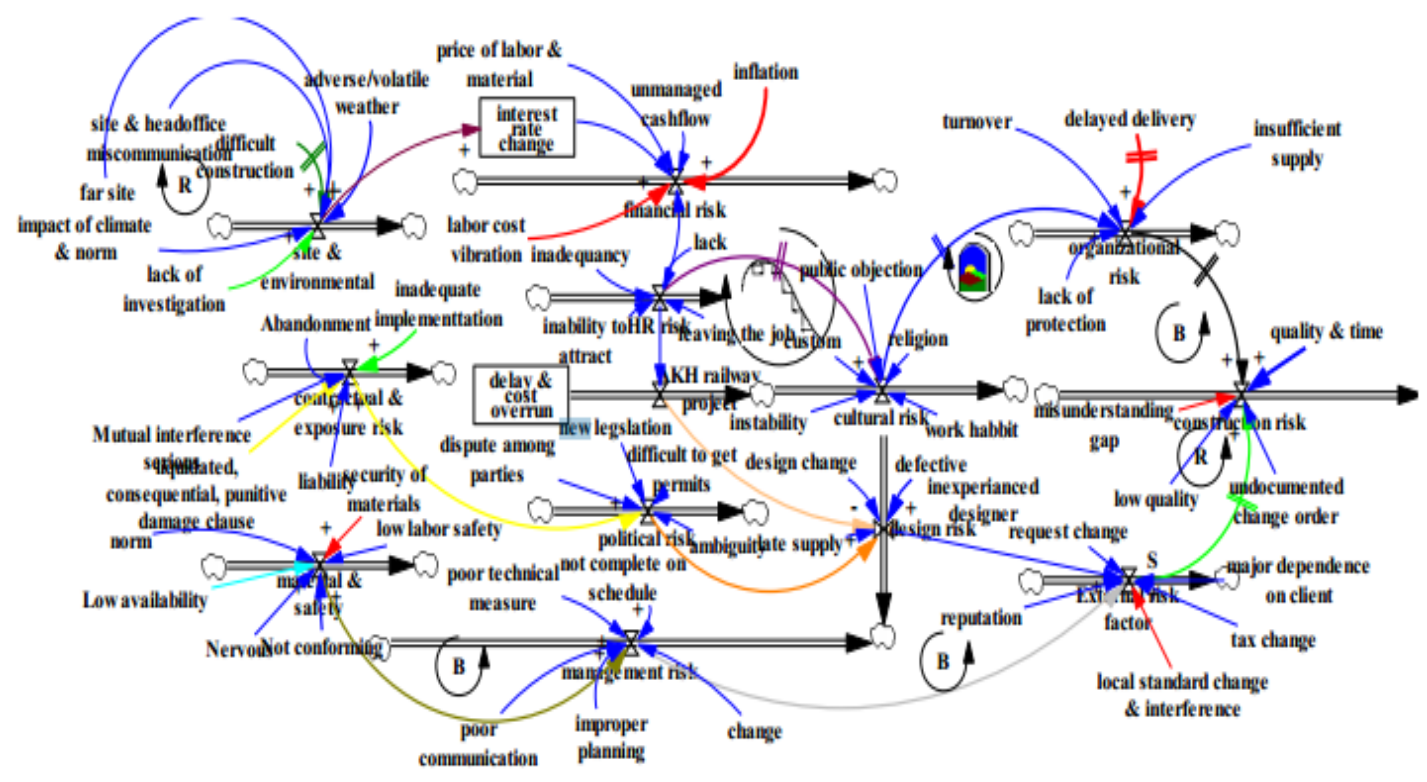

Figure2. Overall general risk factors relationship diagram

Analysis1. Working hours per day $=8 \mathrm{hrs} /$ day

- Over time $=2 \mathrm{hrs} /$ day

- Working days $=28$ days $/$ month

- Number of workers $=8398 \mathrm{employes} /$ number

- Payment scale of the project has $\min =4.3 \mathrm{ETB} / \mathrm{hr}$. up to Max=375 ETB $/ \mathrm{hr}$. Which means even if the project is late at a minimum $1 \mathrm{hr}$. $\{\min \}$ 36, 111.4ETB and $\{$ Max $\} 3,149,250 E T B$ would be overrun cost of the project. And the fixed total cost also \$5.383billionUSD 


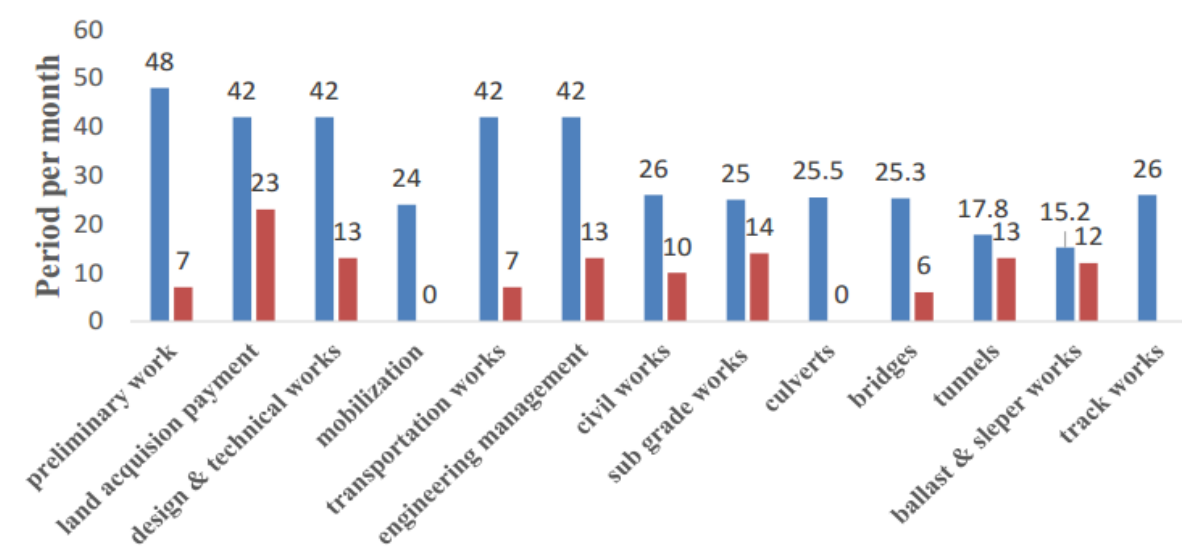

Figure3. Tasks which are performing in the project construction

Therefore all 16 types of risks are quantified independently through fuzzy. Hence due to there value the output of AHP is known. Because of that Four selected extreme effects for delaying and cost overrun on this project are;

I. Financial risk

II. Culture \& land nature of the community

III. Design error and redesign procedure

IV. Pre-operation poor management like land acquis ion procedure $\&$ right of way

Hence the above four identified major risks of the project are not existing solely. But it has another root cause and related risks of one another. So that mentioning the relationship model might be better for further investigation by using system dynamics causal relationship diagram. Verification is related with building the system dynamics right. It consists of the combination of numeric integration method $\&$ step size, checking all equations, inputs of errors, testing sub models and structures. Common data of the software are;

1. Initial time $=2012$ as starting point of zero and the end of 2018 as final time 42

2. Time step $=0.25$ with flow and stock

3. Units $=$ Dmnl Inflow $=$ constant number, fraction, rational number, decimal and mathematical formulas Outflow=risk exposure and loss of economy Risk $=$ Probability*Loss

While validation concerned with building the right system dynamics model. Through limited assumption or using other things it is the task of demonstrating as the model is whether the reasonable representation of the actual system or not.
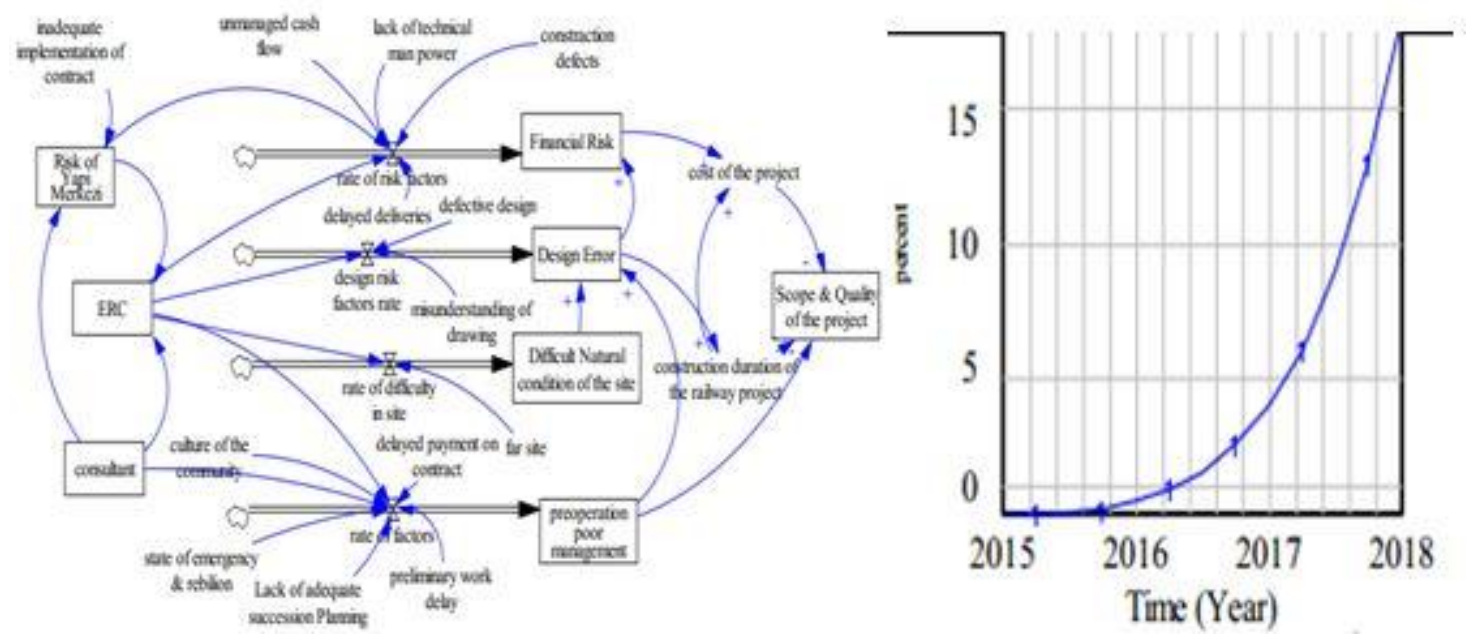

Figure4. Quadrupled constraints of risk rate impact on three parties of AKH railway project 


\section{VALIDATION AND VERIFICATION OF THE SD MODEL}

Here the above figure shows the only four extremes but they included other so many related causes which fosters the delay, cost over run and not qualified work of the project. Usual model purpose tests are the following; Boundary adequacy (whether the model is consistent with knowledge of the real system relevant into the model purpose), Dimensional consistency (to ensure that all variables are mathematically consistent \& further to have variables that have real world meaning), Structure assessment (to assess the appropriateness of the model boundary in terms of the model purpose), Parameter assessment (to estimate the values of each parameter in terms of its reasonability), extreme conditions (whether the model behaves in a realistic fashion no matter how extreme the inputs or policies imposed on the system), Integration error (to make sure that the model is not sensitive to the choices of time step/integration method), Behavior reproduction (to assess a models ability to reproduce the behavior of interest in the system) and Sensitivity analysis (to test the robustness of the model behavior in uncertain conditions).
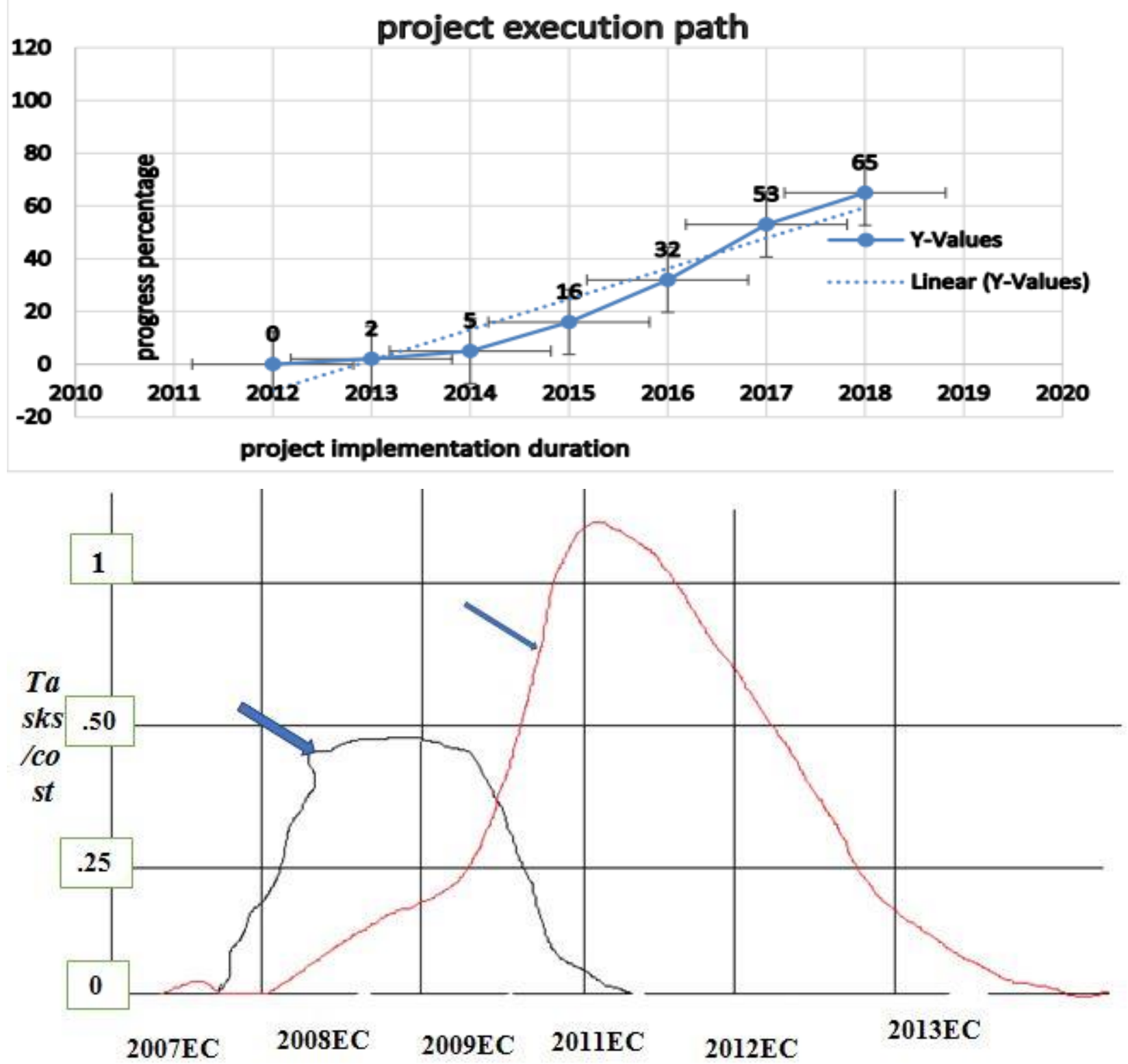

Time

Figure5. Original work plan \& shifting indication graph 
The project progress now is extended 2.5 years out of the plan. But since they deployed the output of this paper will reduced into 2years of overtaking the calculated risk. Having this in mind the basis for the assignment of the ownership for the risks is considered directly from the allocation checklists. So

that Risk response methods ERC holds 38number of risk from total of 81 and 33.6\%. ERA 3 in number and $2.7 \%$. Similarly, Yapi Merkezi 41 in number with $36.3 \%$. while by being reason of entrance ERC 52, 43.7\% Yapi Merkezi 39, 32.8\% and Community 6, 5.1\% respectively. Therefore, risk is properly allocated as per the percentage of risk loving (reason of entrance) and risk taking from impact to all other 8 parties of the AKH railway project.

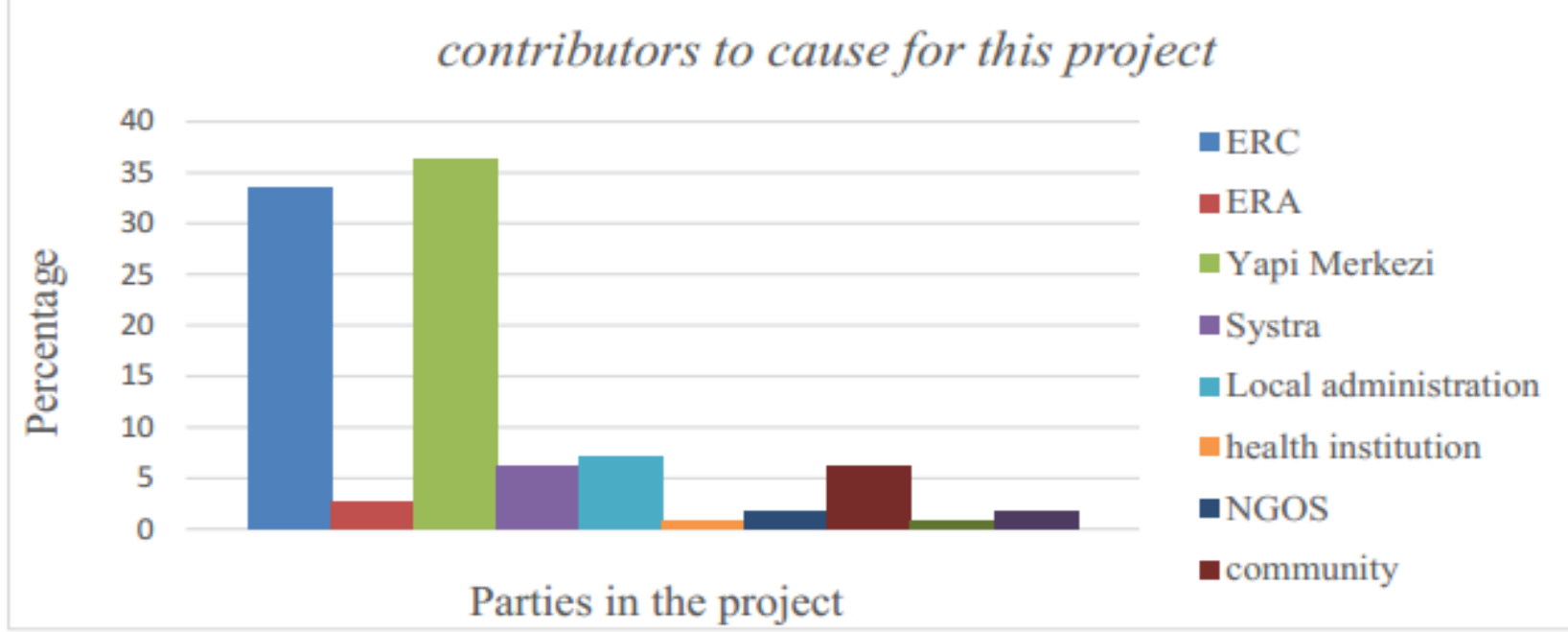

Figure6. Contributors' risk as a cause

In this study risks occurred are respond by two cases; which is for threats and opportunities. There are unlimited number of risks in this project both spontaneous and sporadic risks. Responses for threats are the following;

Table2. Number of risk factors for each risk response measure

\begin{tabular}{|l|l|l|l|}
\hline No & Risk response measures & Number of risk factors & $\%$ out of 81 risk factors \\
\hline 1 & Risk retention & 12 & $14.8 \%$ \\
\hline 2 & Risk reduction & 23 & $28.4 \%$ \\
\hline 3 & Risk transfer & 8 & $9.9 \%$ \\
\hline 5 & Risk avoidance & 26 & $32.1 \%$ \\
\hline 6 & Contingency allowance & 3 & $3.7 \%$ \\
\hline 7 & Sharing & 9 & $11.1 \%$ \\
\hline
\end{tabular}

From spontaneous religious instability, state of emergency, earth quake etc. and from the sporadic lack of communication between parties, sliding effect of tunnels, operators damping and other sever impacts. Here is that local contractor's reason of less involvement in such a project because of more risks happening in the project erection or operation. The reason is that Construction projects are extremely complex, consisting of multiple interdependent components, highly dynamic, involve multiple feedback processes, nonlinear relationships, Involve both hard (quantitative) and soft (qualitative) data. Therefore, SD is suited to handle these situations more than any other modeling process" (Farnad Nasirzadeh1, 2008). But it may not able to grouping the risks one from the other. So the best method of resolving is quantifying and mitigating based on the characteristics of each risk.

\section{CONCLuSion}

Developing countries in the world are under the challenge to coupe up the influence and competition of todays globalized world with developed countries. Especially Ethiopia is one of the developing 
countries which could mention first in such circumstances. Just like level of academy, urbanization, engineering technology, manufacturing institutions, personnel training centers etc. should become prerequisite of it or at least to being parallel.

In this research try to assess and identified 81 general risks from literature and 31project risks by in depth interview. Fuzzily quantify the factors from 0 to 1 and AHP method sort out the four major then correlated one another using venism SD model, due that source of risk is 38\% ERC, $41 \%$ Yapi Mekezi and the rest has been caused by others. In contradiction to this $52 \%$ of risk is fallen by ERC and 39\% for Yapi Merkezi but the rest might be on others. Therefore, from the tasks simply possible to estimate the rest $35 \%$ of the overall project progress will extended 31months more than the planned time which is 2-3years delay and regarding the cost will have an over run from $\$ 1.3-2 b i l l i o n$. Which is very big loss not only in the project but also including national wide. This study attempted to respond $14.8 \%$ of risk by retention, $28.4 \%$ of risk by reduction, $9.9 \%$ of risk by transfer, and $32.1 \%$ of risk by avoidance, $3.7 \%$ of risk by sharing \& $11.1 \%$ of risk by contingency allowance. But it is not enough it is very little relative to the problem.

To the Railway Corporation has a lot of tasks in national level, as a result it seems like very busy. To reduce busyness and simplify things in a short period of time it is better to establish risk management policies and staffs as a department. Because by purchasing safety materials impossible to overcome uncertainties in other NRWN of the country. The other thing would like to recommend is beside source of financing to operate the project. After phase one $270+100 \mathrm{~km}$ of the project completed, the second phase $120 \mathrm{~km}$ was have not finance, it is the main cause of this project delay. So whether borrowing or other source of financing are considered ought to be get a big and urgent attention. Because if the source of finance is too late the project progress will automatically have switched off. All staffs of the ERC 102 employee in AKH railway project it shall better only if you have all relevant information's to the researcher or to any other visitors regarding your profession or office information required to fill and you have to have organized data sittings. Because there were restricted areas for researchers in the project site.

\section{REFERENCES}

[1] Abush Ayalew, 2018. Managerial accounting, page 345, Addis Ababa, Ethiopia

[2] Ng, M. L., 2007. Risk allocation in the private provision of public infrastructure. International Journal of Project Management, 25(risk allocation), p. 11.

[3] Abdelaziz Berrado*, 1. E.-M. E.-K. A. C. a. M. K., 2011. A Framework for Risk Management in Railway Sector: Application to Road-Rail Level Crossings. The Open Transportation Journal, 5(Risk Management in Railway), p. 11.

[4] Abiselom, M., 2016. modeling \& analysis of the life cycle cost of Addis Ababa-Djibouti. AAUthesis.

[5] Agumba, B. Y. R. a. a. J. N., 2016. Risk management in the construction industry: a new literature review. MATEC Web of Conferences, 66(Risk managemen), p. 6.

[6] Australia, C. o. S., 2009. AS/NZS ISO 31000:2009 Risk management-Principles and guidelines. Australia, Australian/New Zealand Standard ${ }^{\mathrm{TM}}$.

[7] baas, s., 2008. Disaster risk management systems analysis A guide book. 1st ed. Rome: Food and Agriculture Organization of the United Nations.

[8] berestein, p. 1., 1998. against the Gods the remarkable story of risk. 2nd ed. singapore: john wiley \& sons inc.

[9] Cassidy, B., 2006. Risk Management and Corporate Governance in Local Government. Galway County, Excellence in Governance through best practise risk management IPB. comcover, A. g., n.d.

[10] educator., 8. e. a., 2015. Enterprise Risk Management:Minnesota State Colleges and Universities. Minnesota, The Minnesota State Colleges and Universities system is an Equal Opportunity employer and educator.

[11] ERC, 2011. awash wolidya EIA reports in 4 lot, Ethiopia: ERC.

[12] F. Nasirzadeh, M. K. \&. M. R., 2013. System Dynamics Approach for Quantitative Risk Allocation. Intternattiionall Journall off Industtriiall Engiineeriing \& Producttiion Research, 24(Quantitative Risk Allocation), p. 10. 
[13] F.Cooper, 2005. project risk management guidelines managing risk in large projects \& complex procruments. broadleaf capital international. Farnad Nasirzadeh1, A. A. M. K., 2008. System dynamics approach for construction risk analysis. International Journal of Civil Engineerng, 6(risk analysis), p. 12.

[14] Farnad Nasirzadeh, A. A. ,. M. K. \&. S. H., 2008. Integrating system dynamics and fuzzy logic modelling for construction risk management. Construction Management and Economics, 26(risk management), p. 17.

[15] Farnad Nasirzadeh, A. A. a. M. K., 2008. Dynamic risk analysis in construction projects. NRCResearch Press, 35(risk analysis), p. 13.

[16] Fazleena Badurdeen, M. S. K. W. B. W. F. J. A. I. J. T. J. G. D. I. a. B. B., 2013. Quantitative modeling and analysis of supply chain risks using Bayesian theory. Journal of ManufacturingTechnology Management, 25(Quantitative modeling), p. 25.

[17] 105 Gary Stoneburner, A. G. a. A. F., 2002. Risk Management Guide for Information TechnologySystems. U.S., Recommendations of the National Institute of Standards and Technology.

[18] Gashaw, T., 2016. Dynamic Risk Modeling and Analysis in Addis Ababa Road Construction Projects. thesis in $A A U$ industrial eng., june, p. 98.

[19] James H. Paek, Y. W. L. J. H. O., 1993. PRICING CONSTRUCTION RISK: FUZZY SET APPLICATION. Journal of Construction Engineering and Management, 119(PRICING CONSTRU CTION RISK), p. 14.

[20] Jian Sun1, a. Y. T. a. W. X. b., 2014. Schedule Risk Management of Railway Station Project. Applied Mechanics and Materials, 587-589(Risk Management), p. 7.

[21] Lark, J., 2015. a practical guide: for SMEs ISO 31000 risk management. Switzerland, Vernier, Geneva .

[22] M.Ghaharamanzadeh, 2013. Managing risk of construction projects the case of Iran. university ofeast.

[23] Ogunlana, P. K. D. a. S. O., 2004. Selection and application of risk management tools and techniques for build-operate-transfer projects. Industrial Management \& Data Systems, 104( risk management tools and techniques), p. 16.

[24] Nigussie Ayele teka, 2014 Talaku T'Kur a historical novel book translated into Amharic

[25] sons, j. w. a., 2003. project risk management: processes, techniques, \& insights. university of southsampton. Stuart Rosenberg, J. M., 10`6. Risk Management In College Fraternities: Guidance From Two Faculty Advisors. Contemporary Issues in Education Research, 9(risk management), p. 8.

[26] Viviane GRUBISIC*, E. Z. Y. A. A. D., 2015. A FRAMEWORK FOR CATEGORIZING RISKS IN HIGH SPEED TRAIN (HST) PROJECTS: THE EXAMPLE OF THE FIRST HST IN BRAZIL. TRANSPORT PROBLEMS, 10(CATEGORIZING RISKS), p. 10.

[27] WANG Lina, L. Y. E., 2011. Research on Risk Management of Railway Engineering Construction. International Conference on Risk and Engineering Management, 1(Risk Management of Railway), p. 7.

[28] Zhang, Y., 2016. Selecting risk response strategies considering project. International Journal ofProject Management, 34(risk response), p. 12.

Citation Mequanint Birhan (2020)"Managing Risks in a Project Implementation: A Case of Awash Kombolcha Haragebeya Railway Construction Project”, International Journal of Modern Studies in Mechanical Engineering, 6(2), pp. 51-61. DOI: http://dx.doi. org/10.20431/2454-9711.0602005

Copyright: (C) 2020 Authors, This is an open-access article distributed under the terms of the Creative Commons Attribution License, which permits unrestricted use, distribution, and reproduction in any medium, provided the original author and source are credited. 